\title{
Power Generation and Heating Performances of An Organic Rankine Cycle Driven by Parabolic Trough Collectors
}

\author{
R. Ait El Cadi ${ }^{1,2, *}$, N. Selhaoui, \\ B. Abnay, A. Aharoun \\ ${ }^{1}$ Laboratory of Thermodynamics and Energy (LTE), \\ University IBN ZOHR, faculty of science BP 8106 - City \\ Dakhla, Agadir, Morocco.
}

\author{
B. El Ghazzani, S. Bouadi, \\ K. Bouabid, A. Ihlal \\ ${ }^{2}$ Laboratory of Materials and Renewable Energy (LMER), \\ University IBN ZOHR, faculty of science BP 8106 - City \\ Dakhla, Agadir, Morocco.
}

\begin{abstract}
A detailed performance model of a $4 \mathrm{MW}$ small scale parabolic trough solar thermal power plant, coupled to an Organic Rankin Cycle in Ait Baha cement factory was built based on TRNSYS software to study the performance of the system throughout the day using experimental data from the operating system. The electric power output from the coupled system at a given incident radiation depends on the product of the solar field efficiency and the heat recovery system efficiency. Also, to put the item on the seasonal climate change in our location, a simulation for the summer and winter solstices, the autumn and spring equinoxes were considered. The main objectives of this work are to evaluate the optical and the thermal behaviour of parabolic trough collectors considering average weather data and to predict the performance of the Organic Rankine Cycle.
\end{abstract}

Keywords- Solar energy; parabolic trough collectors; solar concentration; efficiency; optical performance; Organic Rankin Cycle.

\section{INTRODUCTION}

Global increases in the population number and the scope of industrialisation, transportation and economic development have led to greater energy consumption. Today, More than $80 \%$ of the world's primary energy consumption is produced from fossil fuels [1]. Irrespective of the environmental arguments, to reduce or eliminate the country's high dependency on fossil fuel imports, it is necessary to increase and provide electricity production by new resources. In the long run, renewable sources are the best value alternative, many regions of the world abound in free solar energy, while in some other regions, hydropower, wind and other types of renewable energy sources constitute a logical option.

CSP system is one of the several types of solar thermal energy conversion technology for high and middle temperatures that generate thermal energy by means of concentrated sun irradiation [2]. Parabolic trough technology has proven to be the most mature and lowest cost solar thermal technology existing today. As a result, most of the projects for the construction of commercial solar thermal plants are based on this type of collector. Many factors influence the performance of such installation, which include, on the one hand, the geometry and shape of the reflectors, the optical performance of the reflector, the absorption and loss in the system. The problem that influences the concentrated solar power plants is the climate change as well as disturbance occasioned by forced outages such as at night or in the case of storms or the need to make repairs or simply to perform maintenance work at the plant.

The industrial sector represents the biggest share of the total energy consumption, at an average of $30 \%$ of the total primary energy consumption. The largest part of these energetic demands comes in the form of heat below $250{ }^{\circ} \mathrm{C}$ where the use of solar energy is a suitable option. The industrial process heat in high and medium temperature range has been identified as a very promising and unexplored sector for solar thermal energy. The performance of the parabolic trough has proven that this technology is an excellent alternative for industrial exploitation.

This work presents a detailed study of a small scale solar power plant composed by parabolic trough concentrators coupled to a Heat Recovery System (HRS) installed at Ait Baha cement factory. By means of this system it is possible to increase the electricity production of the existing cogeneration.

\section{MODEL DESCRIPTION OF AIT BAHA POWER PLANT}

In this section, a description of Ait Baha cement plant ORC and the proposed solar plant is provided and details about the working fluids and systems equations are presented. Also, the methodology followed for modelling the coupled system in TRNSYS environment is detailed.

\section{A. System description}

The investigated parabolic trough solar plant is considered to be located in Southwest Morocco (98'6.0" N, 30 13 '1.0" $\mathrm{W})$ at Ait Baha cement plant. The solar thermal power plant, illustrated in Fig.1, consists of solar collector system and Organic Rankine Cycle for the power block. The solar collector system is a series of parabolic concentrators, in which the inner lining of reflectors concentrates solar energy on an absorber tube that is installed along the focal length. The solar field has a total active aperture area of 5'875 $\mathrm{m}^{2}$, used to heat up the heat transfer fluid (Therminol VP1) from $290^{\circ} \mathrm{C}$ to $393^{\circ} \mathrm{C}$ under design conditions. Geometric and optic parameters of the collector considered are summarized in Table 1. 


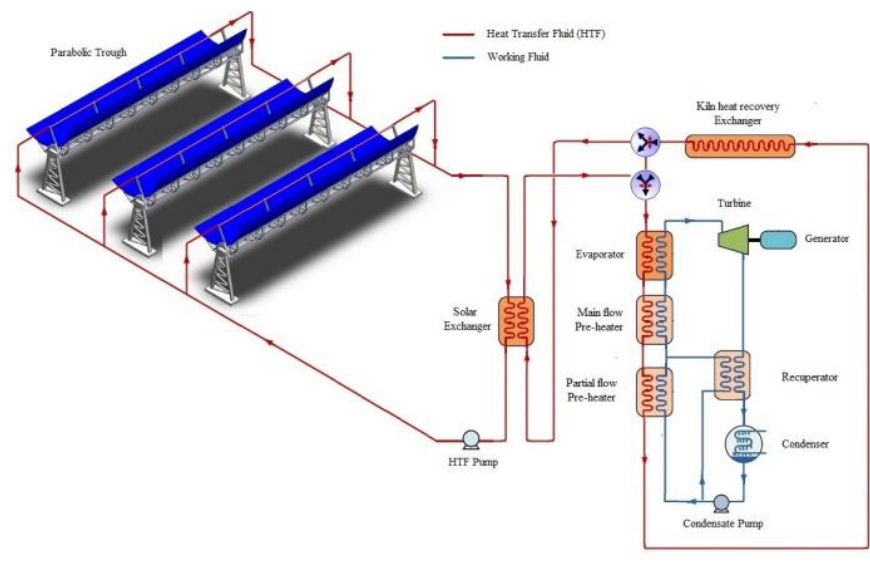

Figure 1: Flow diagram of integrated parabolic solar collector system and the Organic Rankine Cycle.

TABLE I. TECHNICAL GEOMETRICAL AND OPTICAL PARAMETERS OF THE COLLECTORS CONSIDERED.

Eurotrough-150 [3]

\begin{tabular}{l|l}
\hline Module size & $5.76 \mathrm{~m} \times 12.27 \mathrm{~m}$ \\
Rim angle & $80.3^{\circ}$ \\
Row spacing & $14 \mathrm{~m}$ \\
Concentration ratio & 82 \\
Intercept factor & 0.92 \\
Mirror reflectivity & 0.92 \\
Focal length & $1.84 \mathrm{~m}$ \\
Receiver & Schott PTR70 \\
Absorber & Stainless steel \\
Inner diameter & $66 \mathrm{~mm}$ \\
Outer diameter & $70 \mathrm{~mm}$ \\
selective surface Absorptance: & 0.94 \\
selective surface Emittance: & 0.1 at $400^{\circ} \mathrm{C}$ \\
Glass envelope & Borosilicate (AR coated) \\
Internal diameter & $109 \mathrm{~mm}$ \\
External diameter & $115 \mathrm{~mm}$ \\
Transmittance & 0.95 \\
Heat transfer fluid & Therminol VP1 \\
Maximum fluid temperature $\left({ }^{\circ} \mathrm{C}\right)$ & 393 \\
Alignment & North-South \\
\hline
\end{tabular}

The ORC module of AIT BAHA cement plant essentially comprises a steam turbine with Wacker® AK 0.65 being the organic working fluid (OWF) coupled with a generator, a recuperator coupled to a condenser combined in a functional unit, a feed pump, pre-heaters (main flow and partial flow), an evaporator and the system piping. Table 2 resumes the fluids proprieties.

TABLE II. PROPERTIES OF HEAT TRANSFER AND WORKING

\begin{tabular}{|c|c|c|c|c|}
\hline \multirow[b]{2}{*}{ Substance } & \multicolumn{4}{|c|}{ Liquid Properties } \\
\hline & $\begin{array}{l}\text { Spec } \\
C_{p}(k\end{array}$ & $\begin{array}{l}\text { heat } \\
\text { g.K) }\end{array}$ & $\begin{array}{c}\text { Density at } 25 \\
{ }^{\circ} \mathrm{C} \\
\left(\mathrm{kg} / \mathrm{m}^{3}\right)\end{array}$ & $\begin{array}{c}\text { Thermal } \\
\text { conductivity } \\
\text { at } 25^{\circ} \mathrm{C}(\mathrm{W} / \mathrm{m} \cdot \mathrm{K})\end{array}$ \\
\hline $\begin{array}{c}\text { THERMINOL } \\
\text { VP-1 } \\
\text { [4], [5] }\end{array}$ & $\begin{array}{c}25^{\circ} \mathrm{C} \\
150^{\circ} \mathrm{C} \\
250{ }^{\circ} \mathrm{C} \\
400{ }^{\circ} \mathrm{C}\end{array}$ & $\begin{array}{l}1.56 \\
1.91 \\
2.18 \\
2.63\end{array}$ & 1060 & 0.136 \\
\hline $\begin{array}{c}\text { Wacker® AK } \\
0.65 \\
{[6],[7]}\end{array}$ & $\begin{array}{l}25^{\circ} \mathrm{C} \\
100^{\circ} \mathrm{C} \\
200^{\circ} \mathrm{C} \\
220^{\circ} \mathrm{C}\end{array}$ & $\begin{array}{l}1.78 \\
2.11 \\
2.52 \\
2.62\end{array}$ & 760 & 0.10 \\
\hline $\begin{array}{c}\text { THERMINOL } \\
\text { SP } \\
{[4],[5]}\end{array}$ & $\begin{array}{l}25^{\circ} \mathrm{C} \\
100{ }^{\circ} \mathrm{C} \\
200^{\circ} \mathrm{C} \\
290^{\circ} \mathrm{C}\end{array}$ & $\begin{array}{l}1.74 \\
2.19 \\
2.54 \\
2.86\end{array}$ & 868 & 0.127 \\
\hline
\end{tabular}

\section{B. Mathematical simulation model.}

A parabolic trough collector consists of a linear parabolic mirror which reflects and concentrates the received solar energy onto a receiver positioned along the focal line, only the beam radiation (DNI) that is directly normal to the collector surface can be focused and thus be available to warm the receiver.

The energy absorbed by the solar receiver is strongly dependent on the optical properties of the reflector, glass envelope and the absorber tube. The following equation is useful for estimating the total solar irradiation absorbed by the receiver of the parabolic trough collector:

$Q_{a b s}=A_{c} \cdot I_{D N I} \cdot \cos \theta_{i} \cdot$ IAM. $\eta_{\text {opt }, \text { mirr }} \cdot \eta_{\text {Shadow }} \cdot \eta_{\text {end.loss }} \cdot \eta_{\text {track }} \cdot \eta_{\text {soiling }}$

Where $\mathrm{I}_{\mathrm{DNI}}$ is the Direct Normal Irradiance, $\theta_{\mathrm{i}}$ is the solar incidence angle, $\mathrm{A}_{\mathrm{c}}$ is the collector aperture area, IAM is the Incident Angle Modifier; $\eta_{\text {shadow }}$ is the factor for solar shading, $\eta_{\text {end,loss }}$ is the factor for the calculation of the relative end loss, $\eta_{\text {track }}$ is the tracking error, $\eta_{\text {opt }}$ is the optical efficiency that accounts for losses due to mirror optics and imperfections, and the soiling factor, $\eta_{\text {soiling }}$, the ratio between average PTC mirror reflectivity during real operation and the nominal reflectivity when the PTC is completely clean.

The optical efficiency is defined as the ratio of the energy absorbed by receiver to the incidence solar energy, for concentrated solar energy system, the efficiency is affected by the absorptivity, the transmittance and the reflectivity of the tube receiver and the glass envelope.

The incidence angle results from the relationship between the sun's position in the sky and the orientation of the collectors for a given location vary over the course of the day (as well as throughout the year) is not equal to $0^{\circ}$ and the reason is that the parabolic trough solar collector is generally horizontal layout, single axis tracking the sun and will heavily influence the performance of the collectors [8].

The incidence angle for a plane rotated about a horizontal north-south axis with continuous east-west tracking to minimize the angle of incidence and the suntracking angle is given by [9]:

$$
\cos \left(\theta_{i}\right)=\sqrt{\cos ^{2}\left(\theta_{z}\right)+\cos ^{2}(\delta) \sin ^{2}(\omega)}
$$

The position of the sun depends on the hour angle $(\omega)$, declination angle $(\delta)$ and the the zenith angle $\left(\theta_{\mathrm{z}}\right)$. The incidence angle modifier (IAM) corrects for some additional reflection and absorption losses. Defined for this work as the incidence angle modifier defined by Duffi et al [10], divided by the cosine of the incidence angle:

$$
I A M=\frac{K}{\cos (\theta)}
$$

The equation for the incidence angle modifier used in the solar field model considered is [11]:

$$
\text { IAM }=1-5.251 .10^{-4} \cdot \frac{\theta}{\cos (\theta)}-2.8596 .10^{-5} \cdot \frac{\theta^{2}}{\cos (\theta)}
$$

For the PTC designed system, considering the environmental conditions such as air temperature and wind speed, a special model is used to design the PTC and the evacuated tube based on Eq. (18) [10], [12]. The numerical model of receiver is based on the energy balance between the 
HTF, receiver, glass envelope and surrounding. To evaluate the useful energy gain transferred to the HTF under steadystate conditions it is necessary to find the collector heat removal factor, FR which shows the effectiveness of the receiver tube and the thermal loss coefficient of the receiver tube, $\mathrm{U}_{\mathrm{L}}$.

$$
\dot{Q}_{u}=F_{R}\left(Q_{a b s, r e c}-A_{r} U_{L}\left(T_{r i}-T_{a}\right)\right)
$$

Where $A_{r}$ is the aperture of the receiver and $\left(T_{r i}-T_{a}\right)$ is the difference in the temperatures between the receiver inlet and ambient temperature.

The heat removal factor, $F_{R}$ is defined as the ratio of heat transfer in the tube to the maximum heat transfer if the fluid temperature was equal to inlet temperature throughout the tube [12] :

$$
F_{R}=\frac{\dot{m}_{H T F} C_{p, H T F}\left(T_{r o}-T_{r i}\right)}{Q_{a b s, r e c}-A_{r} U_{L}\left(T_{r i}-T_{a}\right)}
$$

The thermal efficiency of the PTC collector, in this case, is defined under steady state conditions as [12]:

$$
\eta_{P T C}=F_{R} \eta_{0}-\frac{F_{R} U_{L}\left(T_{i n}-T_{a}\right)}{I_{D N I} \cdot C}
$$

The heat convection loss between the absorber and cover and the thermal conduction between absorber and glass is inconsiderable. The thermal loss coefficient $\left(\mathrm{U}_{\mathrm{L}}\right)$ is calculated by:

$$
U_{L}=\left[\frac{1}{h_{r, a b s-\mathrm{cov}}}+\frac{1}{h_{c, \mathrm{cov}-a t m}+h_{r, \mathrm{cov}-a t m}} \cdot \frac{D_{a b s}}{D_{\mathrm{cov}}}\right]^{-1}
$$

Where $h_{r \text {,abs-cov }}$ is the radiation coefficient from the absorber to the cover, Similarly the convection $\left(\mathrm{h}_{\mathrm{c}, \mathrm{cov} \text {-atm }}\right)$ and radiation $\left(\mathrm{h}_{\mathrm{r}, \mathrm{cov}-\mathrm{atm}}\right)$ coefficient from the glass envelope to the atmosphere have also been considered too.

For the power block, the work $\left(\mathrm{W}_{\text {turb }}\right)$ generated by the ORC system, the thermal efficiency ( $\eta_{\mathrm{ORC}}$ ) of the ORC system and the net power output $\left(\mathrm{W}_{\mathrm{ORC}}\right)$ are respectively, given by the following equations.

The turbine power output is calculated using the enthalpies of the turbine inlet, $\mathrm{h}_{\text {in }}$, and outlet, $\mathrm{h}_{\text {out }}$, multiplied by the mass of the vapour $\mathrm{M}$.

$$
W_{\text {turb }}=\dot{m}_{\text {OWF }}\left(h_{\text {in }}-h_{\text {out }}\right)
$$

The power consumed by the OWF feed pump obtained from the shaft power required by the pumping process and the overall pump efficiency is expressed as follows:

$$
W_{\text {pump }}=\frac{W_{\text {Shaft }}}{\eta_{\text {pump }}}=\frac{\dot{m}_{\text {OWF }}\left(h_{\text {out }}-h_{\text {in }}\right)}{\eta_{\text {pump }}}
$$

The net ORC power output is calculated based on the pump power consumption as follows:

$$
W_{\text {ORC }}=W_{\text {turb }}-W_{\text {pump }}
$$

The ORC thermal efficiency $\eta_{\mathrm{ORC}}$ is defined as the cycle net power output WORC divided by the recovered heat $\mathrm{Q}_{\text {oil }}$ :

$$
\eta_{\text {ORC }}=\frac{W_{\text {ORC }}}{Q_{\text {oil }}}
$$

\section{Model validation}

In order to model the studied solar thermal plant with the ORC system, TRNSYS (Transient System Simulation Programme) is used [13]. This software offers an extensive library of components to model power cycles in addition to providing TESS and STEC libraries. In this paper, we create a solar field model rather than the complete power plant to predict the optical efficiency and the thermal behaviour of the parabolic trough solar plant used for the ORC system under Ait Baha, Agadir, Morocco weather conditions.

After building the dynamic model of the thermal power system in TRNSYS, the simulation strategy consisted of entering experimental data as inputs to the simulation model. The temperature of the thermal oil as a heat source is among the information used for this purpose. Also, the pressures of the evaporation and condensation are used as inputs for the validation part. The turbine was modelled in TRNSYS using a flow following turbine and a generator model, where the maximum power produced is limited to $2 \mathrm{MWe}$.

A $600 \mathrm{~m}$-long parabolic-trough loop consisting of Schott PTR70 receivers from SCHOTT [14], [15], is chosen for model validation. The solar field component assumes the use of parabolic trough collectors of the type EuroTrough ET150 with Schott PTR70 absorber tubes. Collector loop configuration consists of four collectors, arranged in two parallel rows of two collectors each. Collector ET150 is made up of twelve modules of $12.27 \mathrm{~m}$ long. Nominal mass flow through the collector loop is around $7.5 \mathrm{~kg} / \mathrm{s}$, in order to have a $100{ }^{\circ} \mathrm{C}$ temperature increment in oil (from $293{ }^{\circ} \mathrm{C}$ at the collector loop inlet to $393{ }^{\circ} \mathrm{C}$ at the collector loop outlet).

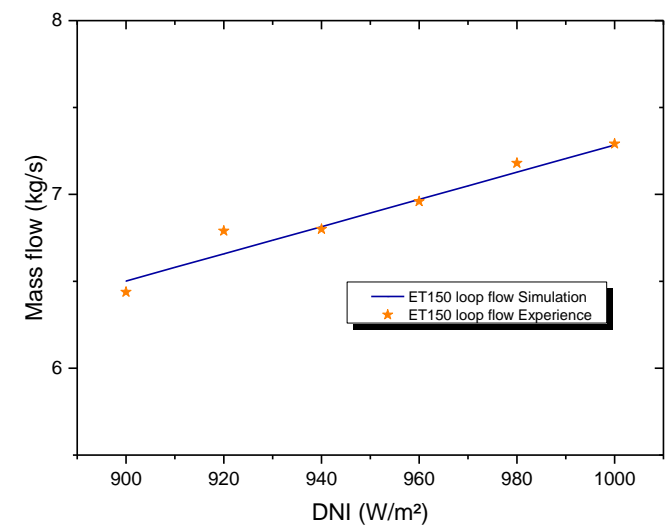

Figure 2: Comparison of measured data and simulation results, HTF mass flow rate in the solar field

The model validation for the solar plant with the variation of mass flow rate induced by DNI variation is presented in Fig. 2 with a maximal relative deviation of less than $2 \%$. There is a very good agreement between simulation results and measured data which shows not only the reliability of the solar field model but also proves that the used control for the solar field operation is very close to reality.

Table 3 includes a comparison between the values of turbine inlet and outlet temperature $\left(\mathrm{T}_{\text {inlet,Turb }}, \mathrm{T}_{\text {outlet,Turb }}\right)$, the condenser outlet temperature $\left(\mathrm{T}_{\text {outlet,Cond }}\right)$, and the temperature at the outlet of the split ( $\left.\mathrm{T}_{\text {outlet,Split }}\right)$. By comparing the 
experimental results to the simulation performed, the electric power and the system thermal efficiency obtained for $\mathrm{T}_{\text {in,Evap }}=246.85{ }^{\circ} \mathrm{C}, \mathrm{T}_{\text {in,water }}=28^{\circ} \mathrm{C}, \mathrm{P}_{\text {Evap }}=5.38$ bars, $\mathrm{P}_{\text {Cond }}=0.14$ bars, are very similar.

Once the system modelling is validated against real site data, the performance of the solar field between the standard four days of equinoxes and solstices with the variation of incidence angle for the inclined collector surface was investigated for Ait Baha collector location, orientation, and tracking capability. Then, a simulation was performed for 5 days operation period with a 1-minute time step in order to predict the performance of the coupled system.

\begin{tabular}{cccc} 
TABLE III. & \multicolumn{4}{c}{ THE COMPARISON BETWEEN THE SIMULATION } \\
& AND EXPERIMENTAL RESULTS. \\
\hline Parameters & Experiment & $\begin{array}{c}\text { TRNSYS } \\
\text { Simulation }\end{array}$ & Deviations \\
\hline$T_{\text {inle, }, \text { Turb }}$ & $182.39^{\circ} \mathrm{C}$ & $186{ }^{\circ} \mathrm{C}$ & $3.61{ }^{\circ} \mathrm{C}$ \\
$T_{\text {outlet, }, \text { Turb }}$ & $137.73{ }^{\circ} \mathrm{C}$ & $131.3{ }^{\circ} \mathrm{C}$ & $6.43{ }^{\circ} \mathrm{C}$ \\
$T_{\text {outlet, } \text {,ond }}$ & $48.64{ }^{\circ} \mathrm{C}$ & $48.06{ }^{\circ} \mathrm{C}$ & $0.58{ }^{\circ} \mathrm{C}$ \\
$T_{\text {outlet, } \text { Partial flow }}$ & $127.49{ }^{\circ} \mathrm{C}$ & $125.8{ }^{\circ} \mathrm{C}$ & $1.69{ }^{\circ} \mathrm{C}$ \\
Electric power & $1384.8 \mathrm{~kW}$ & $1392 \mathrm{~kW}$ & $7.2 \mathrm{~kW}$ \\
System efficiency & 0.22 & 0.23 & 0.01 \\
\hline
\end{tabular}

\section{RESULTS AND PROSPECTS}

The meteorological header file (TMY2) was generated using the linear interpolation method with METEONORM. Fig. 3 presents the DNI for the collector surface and ambient temperature variation on four different days and different seasons. The solar radiation reaches its maximum at summer solstice with the highest value of ambient temperature of 27 ${ }^{\circ} \mathrm{C}$. By against the winter solstice always present the minimal changes.

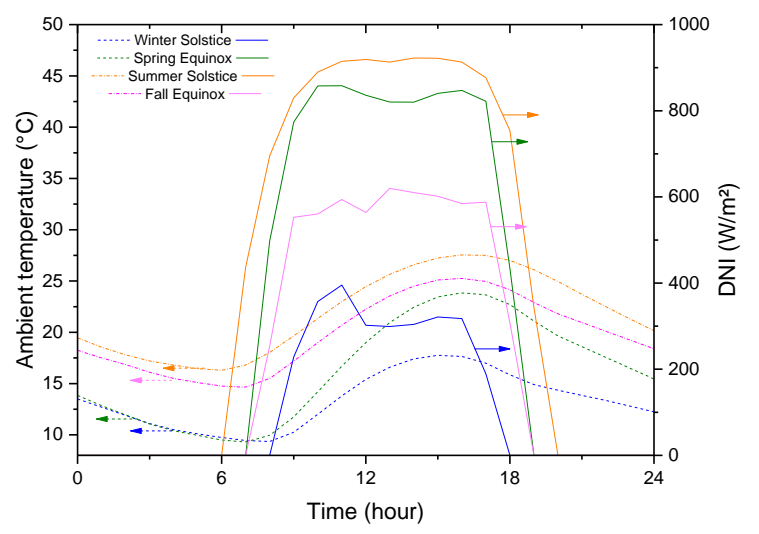

Figure 3: Direct solar radiation for surface and ambient temperature variation on four typical days.

The solar radiation calculated for the collector surface in Fig. 3 takes into account the changes in the incidence angle for the day of the year considered. The incident angle cosine is a characteristic parameter of every day used as an important parameter in the modelling of the daily performance evaluation of the examined system. Practically, at solar noon the incident angle is minimized and its cosine is maximized leading to maximum solar energy utilization, by the optical point of view. Fig. 4 show the variation of incidence angle cosine for the inclined collector surface as calculated for Ait Baha collector location, orientation, and tracking capability.

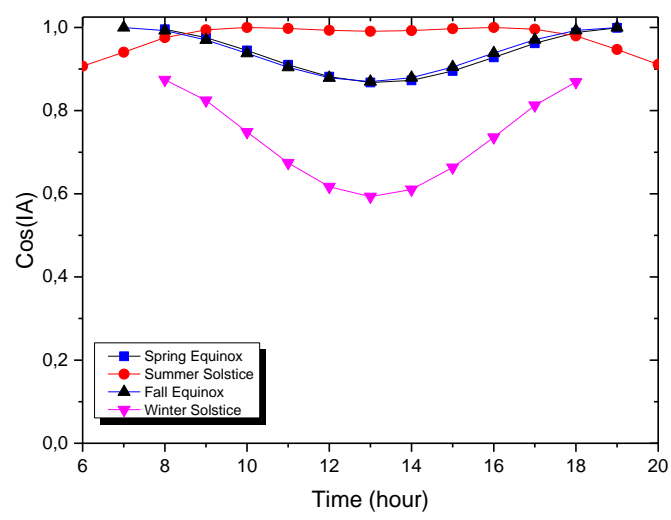

Figure 4: The incident angle cosine variation for inclined surface on four typical days.

The net thermal power of the solar field absorbed by the HTF may be a smart index for comparison of the performance of the solar field between the standard four days of equinoxes and solstices. The thermal power consumed at heating the solar field is already taken into consideration in solar field thermal power value. So it will represent the overall solar field performance well.

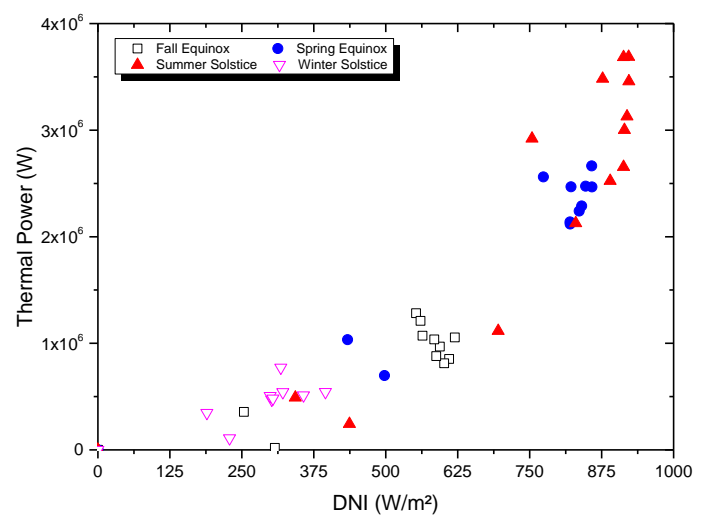

Figure 5: Solar field thermal power variation in function of solar radiation.

Fig. 5 compares the simulated results of the solar field thermal power for the 4 days considered with respect to the bulk fluid temperature of the Therminol VP1. The solar plant achieves its maximum efficiency in June with the increase of solar radiation mainly up to $60 \%$ and 3.68 MWth for 936 $\mathrm{W} / \mathrm{m}^{2}$. Spring and full equinox efficiencies should be taken into consideration too due to the lower wet bulb temperature, which leads to a better performance of the system. 


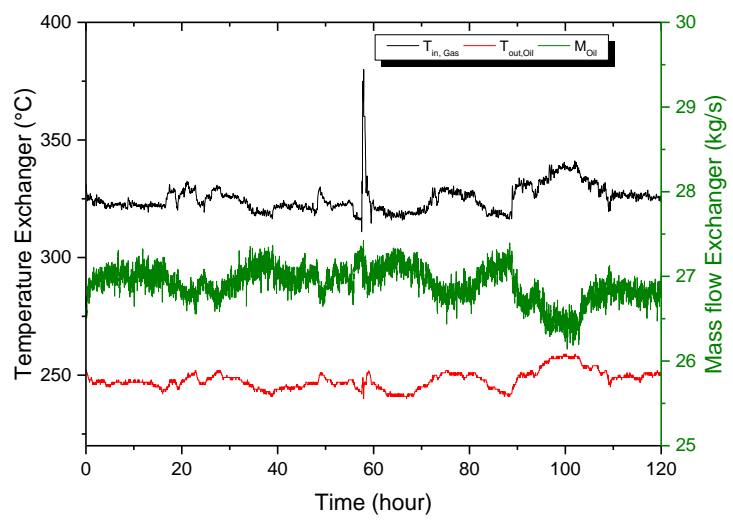

Figure 6: Experimental data from AIT Baha ORC system (Temperature and mass flow at the HR exchanger) during five days.

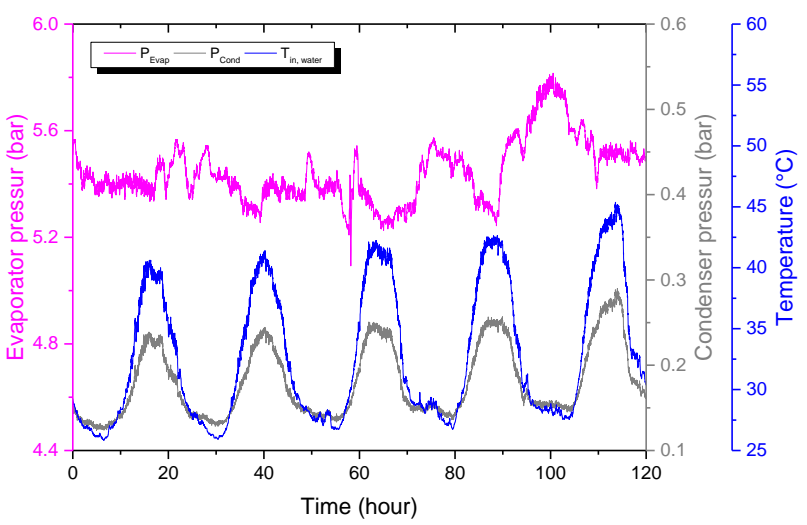

Figure 7: Measured pressure at the turbine inlet, condensing pressure and cooling water temperature during five days.

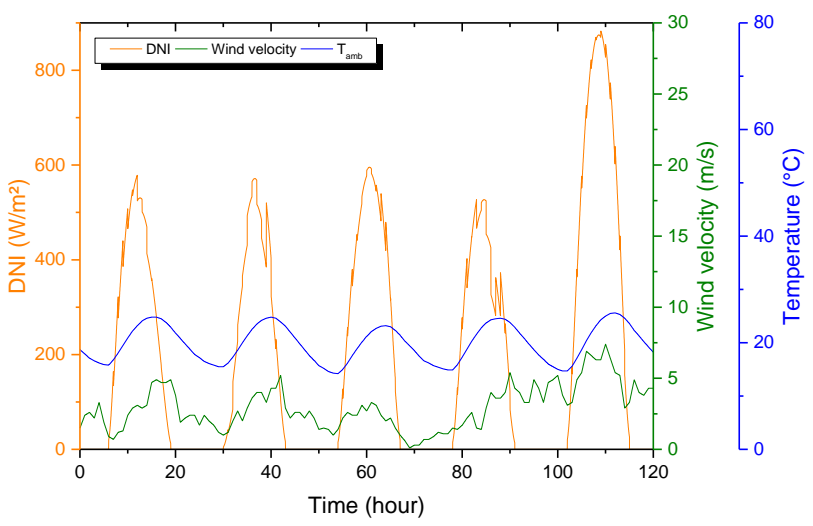

Figure 8: Solar beam irradiation, ambient temperature and wind velocity variation during the five examined days in Jun.

In Fig. 6 and 7, the measured data from the power block, used in the simulation model, are presented for the studied days, including temperature and mass flow at the HR exchanger, cooling water temperature, measured pressure at the turbine and the condenser.Before the simulations of the coupled system started, the initial conditions had to be set first. The initial temperature of the thermal oil in the collector field was set to $290{ }^{\circ} \mathrm{C}$. The initial mass flow rate and pressure of the steam were set to $37 \mathrm{~kg} / \mathrm{s}$ and 5.4 bar, respectively. The temperature of the feed water was set to $30{ }^{\circ} \mathrm{C}$. Fig. 8 illustrates the solar beam irradiation ambient temperature and wind velocity during the five examined days in June.

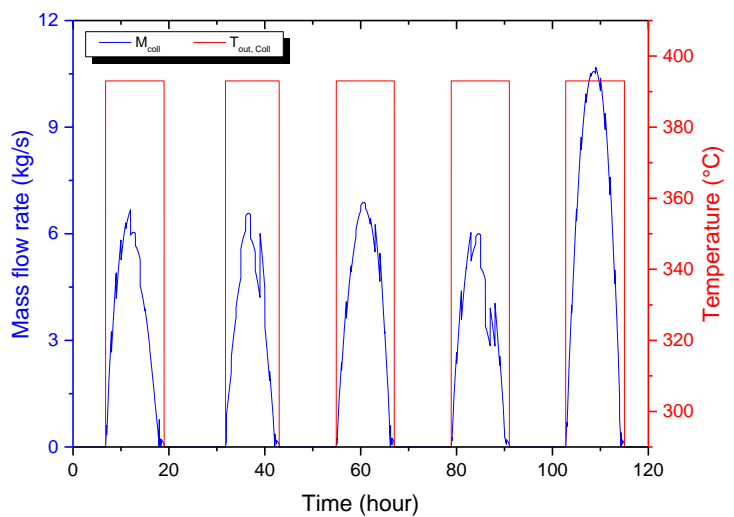

Figure 9: SF outlet temperature $\left({ }^{\circ} \mathrm{C}\right)$ and mass flow rate $(\mathrm{kg} / \mathrm{s})$

After the sunrise, the DNI is increased during the daylight hours. As a result, the HTF temperature increases from the lowest temperature of $290{ }^{\circ} \mathrm{C}$ to the design outlet temperature of the solar field. This stability in the HTF outlet temperature is prevented as a result of the functioning of the HTF main control valve that adjusts the HTF mass flow rate through the collector loops to keep the HTF temperature at solar field outlet of about $393^{\circ} \mathrm{C}$ (Fig. 9). The fluctuations of the intercepted radiation have clearly appeared on the Therminol SP temperature profile at the evaporator inlet. Further minor changes in the evaporating pressure show associated with the shift in the organic fluid temperature profile (Fig. 10). With the solar plant, the OWF can reach a higher temperature up to $230{ }^{\circ} \mathrm{C}$

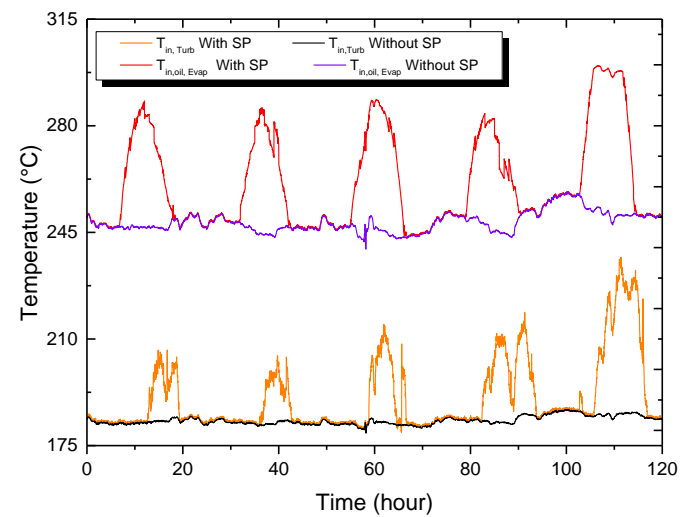

Figure 10: Actual and simulated system response with the solar plant (thermal oil inlet temperature at the evaporator, OWF inlet temperature at the turbine).

Fig. 11 shows a comparison of daily net electrical power production in Ait Baha between actual HRS production and its combination with the solar plant. The points in the graph represent the amount of delivered electrical energy from the plant to the factory grid at each specific day and night. 


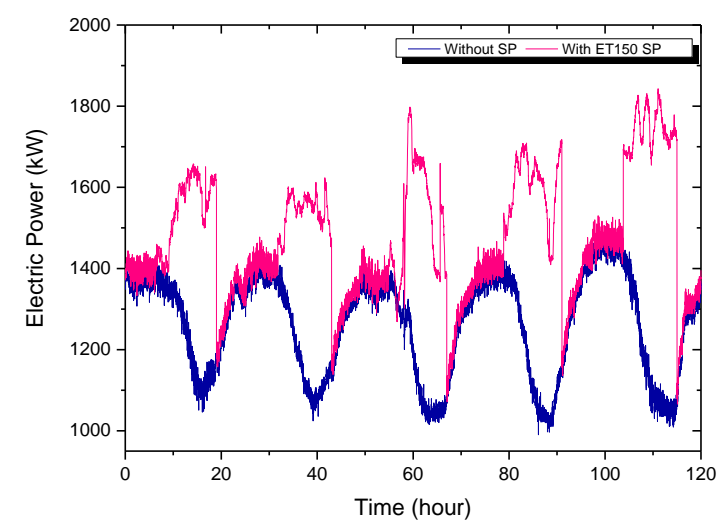

Figure 11: Comparison between actual and simulated net electrical power with solar plant.

Individual deviations in evaporator and condenser pressure with the increase in the thermal oil temperature and the interactions between them cause a deviation in daily electrical energy production as seen in Fig. 15. A maximum increase of $632 \mathrm{~kW}$ in the power production within 1st-5th June. The continuous night operation with the HRS only keeps the power generation of the system at higher values all day.

\section{CONCLUSION}

The performance analysis done in this work is among the most comprehensive and detailed analyses of measured and simulated data from the parabolic trough plants and the ORC power block. It covers a variety of operating days and weather conditions from different seasons. The analysis shows that the simulated mean overall plant efficiency for the operating days of June, September, December and Mars varies between $10 \%$ and $56 \%$ for $936 \mathrm{~W} / \mathrm{m}^{2}$ incident radiations. The simulation results show a very good agreement with measured data in terms of both daily energy yield and component behaviour. The mean deviation between simulated electrical energy yield and measured data is $0.52 \%$. The relative mean deviation of the solar field mass flow rate is evened less and is $2 \%$. This shows that the model is capable of predicting the annual net electricity yield of a large-scale parabolic trough solar plant with a high level of precision and that the tool can simulate the behaviour of the individual components. The model may now be used, e.g., to select the most efficient operational strategy and the optimum number of loops for the purpose to sizing a storage unit for the solar plant to keep the maximum production after sunset.

\section{ACKNOWLEDGMENT}

This work is supported by IRESEN (Institut de Recherche en Energie Solaire et Energies Nouvelles, MOROCCO) in the framework of the project InnoRherm1:"Evaluation des performances des sites thermosolaires (Application au site CSP de la Cimenterie d'Ait Baha) “

[1] “International Energy Outlook 2017,” 2017.

[2] P. Gauché, J. Rudman, M. Mabaso, W. A. Landman, T. W. von Backström, and A. C. Brent, "System value and progress of CSP," Sol. Energy, vol. 152, pp. 106-139, 2017.

[3] M. Geyer et al., "EURO TROUGH - Parabolic Trough Collector Developed for Cost Efficient Solar Power Generation," 11th SolarPACES Int. Symp. Conc. Sol. Power Chem. Energy Technol. Zurich, Switz., pp. 1-7, 2002.

[4] "Heat Transfer Fluids | Therminol." [Online]. Available: https://www.therminol.com/heat-transfer-fluids. [Accessed: 02Apr-2019].

[5] F. C. De Eastman, "Guide de sélection Programme TLC Total Lifecycle Care ${ }^{\circledR}$.”

[6] R. Abbas, A. Schedemann, C. Ihmels, and S. Enders, "Measurement of Thermophysical Pure Component Properties for a Few Siloxanes Used as Working Fluids for Organic Rankine Cycles," Ind. Eng. Chem. Res., vol. 50, no. 16, pp. 9748-9757, 2011.

[7] P. Colonna, N. R. Nannan, A. Guardone, and E. W. Lemmon, "Multiparameter equations of state for selected siloxanes," Fluid Phase Equilib., vol. 244, pp. 193-211, 2006.

[8] P. Silva, A. Giostri, M. Binotti, G. Manzolini, and E. Macchi, "Comparison of Two Linear Collectors in Solar Thermal Plants: Parabolic Trough Versus Fresnel," J. Sol. Energy Eng., vol. 135, no. 1, p. 11001, 2012.

[9] S. Kalogirou, Solar energy engineering: processes and systems, 1st edition. Elsevier Inc., 2009.

[10] John A. Duffie and William A. Beckman, Solar Engineering of Thermal Processes, 4th edition. 2013.

[11] Montes, M.J., Abánades, A., Martínez-Val, J.M., Valdés, M., "Solar multiple optimization for a solar-only thermal power plant, using oil as heat transfer fluid in the parabolic trough collectors," Sol. Energy, vol. 83, pp. 2165-2176, 2009.

[12] S. A. Kalogirou, "A detailed thermal model of a parabolic trough collector receiver," Energy, vol. 48, no. 1, pp. 298-306, 2012.

[13] TRNSYS, "Welcome | TRNSYS : Transient System Simulation Tool." [Online]. Available: http://www.trnsys.com/. [Accessed: 25May-2018].

[14] Andrea Giostri, "Transient effects in linear concentrating solar thermal power plant," Polytechnic University of Milan, Milan, Italy, 2014

[15] K. Noureldin, T. Hirsch, and B. Nouri, "Modelling and Optimization of Transient Processes in Line Focusing Power Plants with Single-Phase Heat Transfer Medium," AIP Conf. Proceedings, SolarPACES 2015, vol. 70022, 2016. 